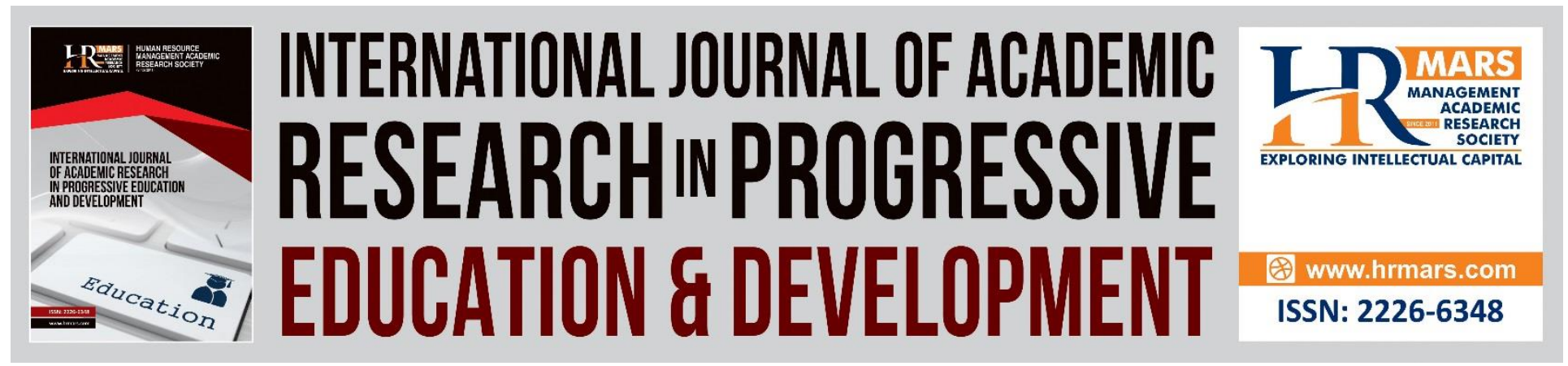

\title{
Technology-Enhanced Language Learning (Tell) Tools: A Survey on Attitude of a Private Secondary School ESL Teachers
}

\section{Keranjit Kaur A/P Hari Singh, Melor Md Yunus}

To Link this Article: http://dx.doi.org/10.6007/IJARPED/v10-i1/8431

DOI:10.6007/IJARPED/v10-i1/8431

Received: 23 December 2020, Revised: 08 January 2021, Accepted: 20 January 2021

Published Online: 18 February 2021

In-Text Citation: (Singh \& Yunus, 2021)

To Cite this Article: Singh, K. K. A/P H., \& Yunus, M. M. (2021). Technology-Enhanced Language Learning (Tell) Tools: A Survey on Attitude of a Private Secondary School ESL Teachers. International Journal of Academic Research in Progressive Education and Development, 10(1), 25-35.

Copyright: (C) 2021 The Author(s)

Published by Human Resource Management Academic Research Society (www.hrmars.com)

This article is published under the Creative Commons Attribution (CC BY 4.0) license. Anyone may reproduce, distribute, translate and create derivative works of this article (for both commercial and non-commercial purposes), subject to full attribution to the original publication and authors. The full terms of this license may be seen at: http://creativecommons.org/licences/by/4.0/legalcode

Vol. 10(1) 2021, Pg. 25 - 35

Full Terms \& Conditions of access and use can be found at http://hrmars.com/index.php/pages/detail/publication-ethics 


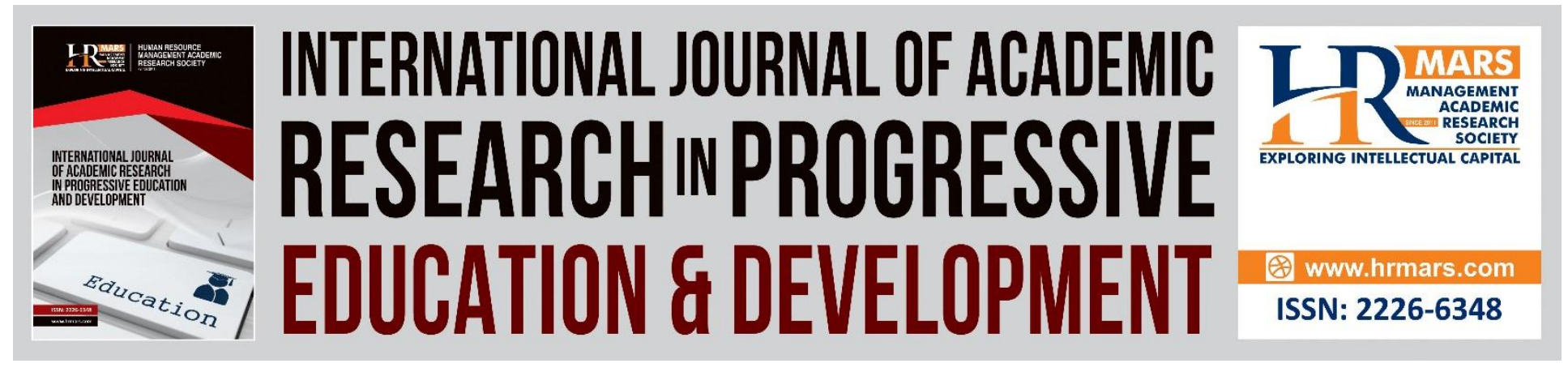

\title{
Technology-Enhanced Language Learning (Tell) Tools: A Survey on Attitude of a Private Secondary School ESL Teachers
}

\author{
Keranjit Kaur A/P Hari Singh, Melor Md Yunus \\ Faculty of Education, Universiti Kebangsaan Malaysia (UKM), Bangi, Malaysia \\ Email: kirangal14@gmail.com, melor@ukm.edu.my
}

\begin{abstract}
The use of Technology-Enhanced Language Learning (TELL) has become a significant part of the learning process in and out of the class. TELL tools use in the classroom is vital for giving teachers opportunities to teach and apply based on the advancement of $21^{\text {st }}$ century. However, studying the attitude of ESL teachers related to TELL tools used in teaching and learning can assist teachers in becoming successful technology users from the context of an Independent Chinese Secondary School. This study aims to determine ESL teachers' attitudes towards the use of TELL tools. A survey research design with a quantitative method was conducted on 30 private secondary school teachers using convenience sampling. The data was collected from a set of five-point Likert scale survey questionnaire and analyzed using descriptive statistics that derived mean and standard deviation through SPSS Version 26. The results discovered that ESL teachers' attitudes in the use of TELL tools based on the four constructs from Technology Acceptance Model (TAM); Perceived Usefulness (PU), Perceived Ease of Use (PE), Behavioural Intention (BI), and Attitude (A) received the highest mean and standard deviation compared to the other statements in the constructs. It is hoped to provide the policymakers with a better picture of the ESL teachers' attitude of using TELL tools from a private secondary school background. Future research can focus on students' attitudes towards the use of TELL tools to further guide in ideal language learning and teaching among teachers and students.
\end{abstract}

Keywords: TELL Tools, Attitude, Private Secondary School, ESL Teachers, Education

\section{Introduction}

English seemed to have an influence on the educational aspect, as the progress of new approaches to teach the language effectively and efficiently resulted in a successful learning environment (Paul, 2017). The beginning of technology and globalization has made English language domineering most countries in the world. As a developing country, Malaysia also used English expansively in nearly all parts of life. Also, Technology-Enhanced Language Learning (TELL) continued to grow in significance as a tool for assisting English language teachers to facilitate and 
initiate language learning for the students (Ali \& Deris, 2019). This reason alone has stimulated many educational researchers to study how TELL tools can be utilized for educational purposes. Thus, TELL tools played a vital role in encouraging and enhancing language learning as well as the effectiveness of any technical tool depends on the knowledge and skills of the ESL teachers who managed and promoted the atmosphere in the classroom.

Next, English as a Second Language (ESL) teachers are known for using suitable teaching methods or approaches based on the competence of the students towards the language (Hardan, 2013). Teachers must be acquainted with technology to integrate TELL tools and the pedagogical aspects of teaching in the classroom. Besides, Private Secondary School or Chinese School is one of the schools under the Malaysia National Education Policy as there are mainly; three types of secondary schools which are Government school, Chinese school and International school. Students from Chinese School take a public examination that is Unified Examination Certificate (UEC) which are based on Chinese syllabus in Malaysia. The Chinese Independent school students' exposure and usage of English is limited (Mansor et al., 2017). Hence, the role of ESL teachers in a private secondary school is to simplify learning using different types of competencies such as pedagogical knowledge, technological aids, and communication skills.

Besides, many researchers highlighted that teaching resources used in present education are technological-based to accommodate to the needs of the 21st century and in supporting them to increase their English language proficiency (Rahim, 2019; Bunting et al., 2021; Ahamed \& Safinas, 2016). The Education Blueprint (2013-2025) focused a main role in determining the future of pre-school-to-university teaching of a child with equality of opportunity of appropriate education, and also implementing English as an additional language in Malaysia. Ahamed \& Safinas (2016) agreed that teaching materials employed in current classrooms are based on TELL tools to cater to the requirements of the students and upsurge their English language skills. Similarly, attitudes of teachers are depending on the accessibility of TELL tools in the classroom (Ghavifekr et al., 2016). So, the attitudes of ESL teachers have been positive towards the use of TELL tools because of its distinctiveness and constructive effects on the teaching and learning process of English.

However, numerous studies have been shown to explore the use of TELL tools in teaching and learning English in the Malaysian context (Lay Shi et al., 2018; Ang et al., 2011; Baron, 2021) , but there are very limited studies that study the use of TELL tools in teaching and learning English on Chinese Independent School ESL teachers because of the variance of technology facilities compared to a non-private school as well as every research varies based on the types of school or heights of teacher. A study led by Ang et al., (2011) specified that a motivated teacher has the opportunity to influence students meaningfully using the precise method of TELL tools. Technology tool application is directly associated to the way teachers understand their usage and usefulness (Taj et al., 2017). Most students tend to lose inspiration and concentration if the teacher used techniques that are not applicable or modern in the classroom. Therefore, the significance of this study is that it addressed a precise sample that is Independent Chinese Secondary School ESL teachers' attitudes on the comprehensive insights based on the Malaysian private secondary school context.

Hence, the understanding and endurance of ESL teachers dealing with TELL tools are important to have a smooth flow in teaching and ensure progress in students' work even though 
they are provided with sufficient technical supports. The objective of this study is to determine ESL teachers' attitudes towards the use of Technology-Enhanced Language Learning (TELL) tools. This study is aimed to answer the following research question: What are ESL teachers' attitudes towards the use of Technology-Enhanced Language Learning (TELL) tools? The rest of the article is structured as follows: First, it begins with an introduction to the topic. This is followed by several past studies in the literature review. Then, the methodology of this study is discussed. Also, the findings and discussion are summarized. Finally, the conclusion, implications, and recommendations for future research are presented in this article.

\section{Literature Review}

Research on the use of TELL tools in the classroom has shown that it makes a supportive and encouraging environment for the teachers to increase their basic skills in terms of quality and quantity of teaching and learning of English (Hanifa et al., 2021). The results of the research were further strengthened by the findings from the study conducted Al-Rahmi et al (2015) who found out it was an effective online resource used in this study is called Quizzes and it is an online game similar to a quiz which is very popular in the field of education. Overall, most of the students were involved during the lesson and using TELL tools such as their computers and mobile phones promote their motivation towards learning English. Likewise, it was also agreed by Sharma (2018) that TELL tools unquestionably facilitated in enlightening the basic skills of each student as it increases the contribution in the classroom activities. Hence, the importance of using the TELL tools in the teaching and learning of English is necessary to maintain the interest of the students and sustain the longer attention span towards the subject matter.

Rahim (2019) agreed that TELL tools allow teachers to differentiate instruction and alter classroom activities and homework assignments, thereby enhancing the learning experience of languages. It was also agreed by Semerci \& Aydın (2018) found that computer-based communication is a beneficial feature for language learning. It lets them gather knowledge and communicate with tools like videos and computer-based communication is a useful tool for learning languages. Zaki \& Yunus (2015) supported this view by suggesting that for effective language learning, access, and exposure to stimulating, authentic as well as comprehensible yet challenging materials in the target language is vital. It is noted that as students become more independent, teachers believed that they should permit and aid students to independently act and think in the classroom. Similarly, TELL tools encouraged learning for teachers and students as well as act as a true educational resource that allows learning to take place effectively. Thus, TELL tools is interdependent with the involvement of teachers in the classroom to ensure and produce a smooth teaching and learning process that will benefit both the teachers and students accordingly.

Next, Technology Acceptance Model (TAM) has been established to be a theoretical model to enlighten and forecast user behavior related to information technology (Tehseen \& Hadi, 2015). It has been extensively studied and proved by various studies that examine the individual behaviors of accepting technology in different constructs of information (Waxman et al., 2003; Sikand \& Kauts, 2016). The questionnaire used for this survey was adapted from Technology Acceptance Model (TAM) theory which represented the four constructs; Perceived Usefulness (PU), Perceived Ease of Use (PU), Behavioral Intention (BI), and Attitude (A). Perceived 
usefulness signified the extent to which they be certain of that via a specific technology will improve their career performance. Perceived ease of us characterized the range to which they are certain that via a specific structure would be unrestricted from effort. Behavioral intention is the level to which the teacher has expressed mindful plans to accomplish or not accomplish approximately definite forthcoming behavior. Attitude is the teacher's optimistic or undesirable awareness about carrying out the target behavior. In a research done by Miangah and Nezarat, (2012), they believed that technology played as an imperative motivator that is supportive for teachers' attitudes in the classroom.

Also, a few studies have been performed relating to teachers' attitude towards the use of TELL Tools (Islam et al., 2016; Kiilu et al., 2018; Albirini, 2006; Akyıldız \& Celik, 2020; Fandino et al., 2019). Kiilu et al., (2018) stated there is a positive relationship between levels of experience and favourable attitudes toward computers or the use of TELL tools based on TAM. It was supported by Islam et al., (2016) studied attitudes toward technology in teaching and learning among students. Findings from this study showed that students used email and internet tremendously to support their study. In an ESL context, Albirini (2006) investigated teachers' attitudes towards the use of TELL tools in teaching. Findings indicated that the independent variables projected positive attitudes of ESL teachers towards TELL tools. Also, Khoshsima et al., (2018) stated the attitudes of TELL tools among teachers have been positive towards the online course because of its exceptionality and positive effects on learning process. Therefore, the attitudes of ESL teachers towards the use of TELL tools is effective and productive compared to traditional teaching methods.

It was agreed by Bullock (2004) stated that teachers' positive or negative attitudes are qualifying or inactivating factors that affect the fruitful integration of technology in ESL teaching. Therefore, teachers who have positive attitudes are more likely to use Web 2.0 tools in class. Furthermore, Looi \& Yusop (2011) showed that the huge majority of ESL teachers have positive attitudes as well. The teachers agreed that TELL tools fascinated students' attention, improve language skills and inspire active participation. It was found that students appeared to notice a related connection between language and social interaction practices. Also, a study by Allam et al., (2020) was directed to determine the effectiveness of technology in classroom activities such as originality and problem-solving. The findings designated that technology in classroom could be used to deliver a reliable and appealing learning experience for students and teachers. So, there are high chances of positive attitudes of ESL teachers towards the use of TELL tools that will increase the success rate of students understanding towards the lesson.

\section{Methodology}

This study employed a survey research design with a quantitative approach to determine ESL teachers' attitudes towards the use of TELL tools. Creswell \& Garrett (2008) stated that a quantitative approach is a research that had significance on digits and figures in the compilation and examination of data. The study was conducted on a sample of $30 \mathrm{ESL}$ teachers working in an Independent Chinese Secondary School at Klang Valley. The participants were chosen based nonprobability sampling technique which is convenience sampling. The reason the ESL teachers were selected because the researcher works in the Independent Chinese Secondary School, more convenient access to the participants, and five to ten years of exposure to the use of TELL tools 
which is sufficient to provide an appropriate response for this study. Creswell (2012) specified that convenience sampling is a type of nonprobability or non-random sampling that respondents of the population encounter certain practical norms such as easy approachability, geographical immediacy, convenience at a certain time, or readiness to contribute are encompassed in the study.

The data was collected using a survey questionnaire for this study to achieve the proposed objective. Mackey and Gass (2005) stated that a survey as a questionnaire is one of the most common means of collecting data on ideas from several groups of participants. The items used in this survey are closed-ended questionnaires which were converted to an online survey in Google Forms because it was not possible to meet teachers face to face as the school was closed down due to Movement Control Order (MCO). The questionnaire comprised of two sections. The first section encompassed queries on demographic information such as gender, age, and qualification. The next section consisted of ten items that determine perceived usefulness, perceived ease of use, behavioral intention and followed by the attitude of ESL teachers towards the use of TELL tools that was adapted from the TAM. The questionnaire was presented in a fivepoint Likert Scale. The questionnaires are anchored by scales consisting (1) totally disagree, (2) disagree, (3) neutral, (4) agree, and lastly (5) totally agree.

The survey questionnaire was created using Google Forms and distributed through a WhatsApp group of ESL teachers from an Independent Chinese Secondary School. This is due to the pandemic that caused a barrier for face-to-face data collection to take place in the school. Next, the teachers who voluntarily participate in this anonymous survey would enter the survey through the link provided to them. From the link, they would be informed about the purpose of the study, the estimated time required for the survey, and results of the survey would be solely used for scholarly purposes only. Once their informed consent had been confirmed, participants were led to the survey questionnaire. To avoid incomplete responses, the function required was activated for every question in the survey questionnaire. The survey questionnaire link was opened and available for responses for two weeks. After that period, receiving responses were ended for the survey questionnaire. The results of the survey that were provided by Google Forms were imported into Microsoft Excel.

Data were analyzed through Statistical Package for the Social Sciences (SPSS) Version 26. The result of the analysis was measured with descriptive statistics such as mean and standard deviation as well as reliability analysis included internal consistency coefficient (Cronbach Alpha) to determine ESL teachers' attitudes towards the use of TELL tools. To certify the reliability of the test, the researcher directed the edited version to five ESL teacher experts who were not a part of the study sample. The result showed that Cronbach's Alpha values of attitudes towards the use of TELL Tools are considered very good because their Cronbach Alpha value is more than 0.7 which is just 0.90 . 
INTERNATIONAL JOURNAL OF ACADEMIC RESEARCH IN PROGRESSIVE EDUCATION AND DEVELOPMENT

Vol. 10, No. 1, 2021, E-ISSN: 2226-6348 @ 2021 HRMARS

\section{Findings}

Table 1. ESL teachers' attitudes towards the use of TELL tools ESL teachers' attitudes

of TELL tools (TAM

Constructs) N

Minimum Maximum Mean Std.

\begin{tabular}{|c|c|c|c|c|c|}
\hline $\begin{array}{l}\text { Perceived Usefulness } \\
\text { (PU) } \\
\text { 1. Using TELL tools } 30 \\
\text { improves } \\
\text { performance }\end{array}$ & 2.00 & 5.00 & 4.4667 & .81931 & 5 \\
\hline $\begin{array}{l}\text { 2. Using TELL tools } 30 \\
\text { increases } \\
\text { productivity }\end{array}$ & 3.00 & 5.00 & 4.6333 & .71840 & 1 \\
\hline
\end{tabular}

Perceived Ease of Use (PE)

3. Learning to use TELL 30 tools is easy for me

4. My interaction with 30

TELL tools does not require much effort

\begin{tabular}{l|l|l|l|l|l|l}
\hline $\begin{array}{l}\text { 5. It is easy for me to } 30 \\
\text { become skilful at using } \\
\text { TELL tools }\end{array}$ & 3.00 & 5.00 & 4.5000 & .68229 & 4 \\
\hline $\begin{array}{l}\text { Behavioural Intention } \\
\text { to Use (BI) } \\
\text { 6. I intend to continue } 30 \\
\text { use TELL tools in the } \\
\text { future }\end{array}$ & 3.00 & 5.00 & 4.5667 & .67891 & 3 \\
\hline $\begin{array}{l}\text { 7. I expect that I would } 30 \\
\text { use TELL tools in the } \\
\text { future }\end{array}$ & 2.00 & 5.00 & 4.3333 & .88409 & 6 \\
\hline $\begin{array}{l}\text { Attitude (A) } \\
\text { 8. Once I start using } 30 \\
\text { TELL tools, I find it hard } \\
\text { to stop }\end{array}$ & 3.00 & 5.00 & 4.6333 & .61495 & 1 \\
\hline $\begin{array}{l}\text { 9. I look forward to } 30 \\
\text { those aspects of my job } \\
\text { that require the use of } \\
\text { TELL tools }\end{array}$ & 2.00 & 5.00 & 4.6000 & .81368 & 2 \\
\hline $\begin{array}{l}\text { 10. I like working with } 30 \\
\text { TELL tools }\end{array}$ & 2.00 & 5.00 & 4.5667 & .77385 & 3 \\
\hline \begin{tabular}{l} 
Valid N (listwise) \\
\hline
\end{tabular} & 30 & & & & & \\
\hline
\end{tabular}


From Table 1, Perceived Usefulness (PU), the respondents showed statement two that is using TELL tools increases my productivity ( $M=4.6333 \mathrm{M}, \mathrm{SD}=.71840 \mathrm{SD}$ ) reported the highest mean and standard deviation out of the other construct that is statement one that is using TELL tools improves my performance out of a five-point Likert scale. In terms of Perceived Ease of Use (PE), the respondents presented statement four that is my interaction with TELL tools does not require much effort $(M=4.5667, S D=.67891)$ reported the highest mean and standard deviation out of the other constructs like statement three that is Learning to use TELL tools is easy for me and statement five that is it is easy for me to become skillful at using TELL tools. Followed by, Behavioral Intention to Use (BI), the respondents showed statement six that is I intend to continue use TELL tools in the future $(M=4.5667, S D=.67891)$ reported the highest mean and standard deviation out of the other construct that is statement seven which is I expect that I would use TELL tools in the future. Lastly, Attitude (A), the respondents depicted that statement eight which is once I start using TELL tools, I find it hard to stop ( $M=4.6333, S D=.61495)$ reported the highest mean and standard deviation out of the other constructs like statement nine which is I look forward to those aspects of my job that require the use of TELL tools and statement ten which is I like working with TELL tools out of a five-point Likert scale. Hence, each statement in the constructs played a significant and major role in determining ESL teachers attitude towards teaching and learning of English by using TELL tools in the classroom.

\section{Discussion}

"What are ESL teachers' attitudes towards the use of Technology-Enhanced Language Learning (TELL) tools"? revealed that the findings of the survey questionnaire supported the TAM model's use to study the attitude of using TELL tools among ESL teachers in which all the four main constructs of the TA model; PU, PE, BI, and A are contributing to the usage of technology in the classroom Data from the literature are in support of the findings of the survey questionnaire of ESL teachers' attitude toward using TELL tools. Looking at construct one, using TELL tools increases my productivity received the strongest mean and standard deviation score among the other constructs of Perceived Usefulness (PU). It was supported by a study showed by Khoshsima et al., (2018) stated the attitudes of using TELL tools among teachers have been positive towards the online teaching because of its exceptionality and positive effects on learning process. Next, for construct two, my interaction with TELL tools does not require much effort received the highest mean and standard deviation score among the other constructs of Perceived Ease of Use (PE). It was agreed by Bullock (2004) stated that teachers' positive or negative attitudes can serve as qualifying or restricting aspects that affect the effective incorporation of technology in ESL teaching and teachers who have positive attitudes are more likely to use Web 2.0 tools in class.

Furthermore, in construct three, I intend to continue to use TELL tools in the future acknowledged the highest mean and standard deviation score among the other constructs of Behavioural Intention to Use (BI). It was supported by a study conducted by Looi \& Yusop (2011) that showed that the vast majority of ESL teachers have positive attitudes, and teachers agreed that Web 2.0 tools attracted students' attention, improve their language skills and encourage active participation. Last but not least, for construct four, once I start using TELL tools, I find it hard to stop stated the highest mean and standard deviation score among the other constructs of Attitude (A). It was agreed by the findings of Allam et al., (2020) to determine the effectiveness 
of technology in classroom activities such as creativity and problem-solving as the results indicated that technology in the classroom could be used to provide an authentic and engaging learning experience for students. In short, based on the four constructs of TAM, it is clearly shown that ESL teachers are more motivated to use TELL tools if it is easy to use and they have the necessary skills to use it in the classroom.

\section{Conclusion}

In conclusion, a survey research design with a quantitative method was conducted to determine ESL teachers' attitudes towards the use of TELL tools. The findings of this study for the research question revealed that ESL teachers' attitude in the use of TELL tools will be a successful way of teaching to enable them to understand their point of view regarding the matter based on the four constructs of TAM. Based on the findings, several implications can be beneficial to further strengthen the existing knowledge. Regarding the ESL teachers' attitudes towards the use of TELL tools, it is acknowledged that when teachers are given the chance to grow professionally, they are to be anticipated to feel appreciated, cherished, and accomplished outcomes. There is still room for improvement in terms of further research based on the findings of the study. Looking at the research question, it can be recommended for researchers to conduct this study from the perspective of other stakeholders such as students, parents, and administrators to confirm that the voices of all are heard and taken into consideration as decisions and progress are made with these TELL tools in the classroom. Hence, the implementation of TELL tools in education is necessary based on the perception of ESL teachers in a private secondary school in facilitating the teaching of English to certify a fruitful 21st century teaching space and prepare students for accomplishment in their upcoming careers.

\section{References}

Ali, M. A. S. \& Deris, F. D. (2019). Vocabulary Learning through Duolingo Mobile Application: Teacher Acceptance, Preferred Application Features and Problems. International Journal of Recent Technology and Engineering (IJRTE), 8(259).

Albirini, A. A. (2006). Teacher's attitudes toward information and communication technologies: The case of Syrian EFL teachers. Journal of Computers and Education, 47, 373-398.

Ang, Y., Wang, Q., Woo, H. L., \& Quek, C. L. (2011). Using Facebook for teaching and learning: A review of the literature. International Journal of Continuing Engineering Education and LifeLong Learning, 21(1), 72-86.

Allam, S. N. S., Hassan, M. S., Mohideen, R. S., Ramlan, A. F., \& Kamal, R. M. (2020). Online Distance Learning Readiness During Covid-19 Outbreak Among Undergraduate Students. International Journal of Academic Research in Business and Social Sciences, 10(5), 642-657.

Akyıldız, S. T., \& Celik, V. (2020). Thinking outside the box: Turkish EFL teachers' perceptions of creativity. Thinking Skills and Creativity, 36 (100649). https://doi.org/10.1016/j.tsc.2020.100649

Bullock, D. (2004). Moving from theory to practice: An examination of the factors that preservice teachers encounter as the attempt to gain experiences teaching with technology during field placement experiences. Journal of Technology and Teacher Education, 12(2), 211-237.

Bunting, L., Segerstad, Y. H. A., \& Barendregt, W. (2021). Swedish teachers' views on the use of 
personalised learning technologies for teaching children reading in the English classroom. International Journal of Child-Computer Interaction. 27(100236): 2-9.

https://doi.org/10.1016/j.ijcci.2020.100236

Baron, N. S. (2021). Know what? How digital technologies undermine learning and remembering, Journal of Pragmatics, 175, 27-37. https://doi.org/10.1016/j.pragma.2021.01.011

Creswell, J. W., \& Garrett, A. L. (2008). The "movement" of mixed methods research and the role of educators. South African Journal of Education, 28(3), 321-333.

Creswell, J. W. (2012). Educational research: Planning, conducting, and evaluating quantitative and qualitative research (4th ed.). Boston, MA: Pearson.

Fandino, F. G. E., Munoz, L. D., \& Velandia, A. J. S. (2019). Motivation and E-Learning English as a foreign language: A qualitative study. Heliyon, 5(9). https://doi.org/10.1016/j.heliyon.2019.e02394

Ghavifekr, S., Kunjappan, T., Ramasamy, L., \& Anthony, A. (2016). Teaching and Learning with ICT Tools: Issues and Challenges from Teachers' Perceptions. Malaysian Online Journal of Educational Technology, 4(2), 38-57.

Hardan, A. A. (2013). Language Learning Strategies: A General Overview. Procedia-Social and Behavioral Sciences, 106(1), 1712-1726.

Hanifa, R. M., Isa, K., \& Mohamad, S. (2021). A review on speaker recognition: Technology and challenges. Computers \& Electrical Engineering, 90 (107005).

https://doi.org/10.1016/j.compeleceng.2021.107005

Islam, Beer \& Slack. (2016). E-Learning Challenges Faced by Academics in Higher Education: A Literature Review. Journal of Education and Training Studies, 3(5).

Khoshsima, Saed \& Arbabi. (2018). Online Teachers' Attitudes toward Using Technology in Teaching English as a Foreign Language. Journal of Applied Linguistics and Language Research. 5(2), 134-148.

Kiilu, Nyerere \& Ogeta. (2018). Teacher-trainee's competency and institutional level of preparedness for adoption of e-learning in selected teacher training colleges in Kenya African Educational Research Journal, 6(2), 73-79.

Looi, C. Y., and Yusop, F. D. (2011). Potential use of social networking tool to assist reading comprehension: Implications for practice and future research. Jurnal Pendidikan, 31(1), 189201.

Mackey, A., \& Gass, S. M. (2005). Second language research: Methodology and design. Lawrence Erlbaum Associates Publishers.

Mansor, N. S., Halim, H. A., \& Rahim, N. A. (2017). Students' perspectives towards innovation of technology in teaching and learning of language. Indonesian Journal of EFL and Linguistics, 2(2), 121-132.

Miangah, T. M., and Nezarat, A. (2012). Mobile-Assisted Language Learning. International Journal of Distributed and Parallel Systems (IJDPS), 3(1).

Rahim, M. N. (2019). The Use of Blended Learning Approach in EFL Education. International Journal of Engineering and Advanced Technology (IJEAT), 8(5C).

Sharma, D. R. (2018). Action Research on Improving Students' Speaking Proficiency in Using Cooperative Storytelling Strategy. Journal of NELTA Surkhet, 5(1): 97-105. 
INTERNATIONAL JOURNAL OF ACADEMIC RESEARCH IN PROGRESSIVE EDUCATION AND

DEVELOPMENT

Vol. 10, No. 1, 2021, E-ISSN: 2226-6348 @ 2021 HRMARS

Semerci \& Aydın. (2018). Examining High School Teachers' Attitudes towards ICT Use in Education.

International Journal of Progressive Education, 14(2), 93-105.

Sikand, D., \& Kauts, A. (2016). Relationship of Teacher Effectiveness, Teacher Stress and Teacher Commitment with Different Dimensions of Creative Management. Scholarly Research Journal for Humanity Science \& English Language, 5(25).

Tehseen, S. \& Hadi, N. (2015). Factors Influencing Teachers' Performance and Retention. Mediterranean Journal of Social Sciences, 6(1).

Taj, I. H., Ali, F., Sipra, M. A., \& Ahmad, W. (2017). Effect of Technology Enhanced Language Learning on Vocabulary Acquisition of EFL Learners. International Journal of Applied Linguistics \& English Literature, 6(3): 263-264.

Paul, W. (2017). Adjectival modification in Mandarin Chinese and related issues. Linguistics, De Gruyter, 43(4), 757-793.

Zaki, A. A., \& Yunus, M. (2015). Potential of Mobile Learning in Teaching of ESL Academic Writing. English Language Teaching, 8(6). 